\title{
RAMBU-RAMBU BIMBINGAN DAN KONSELING ISLAM (PERSPEKTIF MAJELIS TARJIH MUHAMMADIYAH)
}

\author{
Aswar ${ }^{1}$, Nashruddin ${ }^{2}$ \\ STKIP Muhammadiyah Barru \\ aswar@stkipmb.ac.id ${ }^{1}$, nashruddin@stkipmb.ac.id ${ }^{2}$
}

Received: 12-09-2020/Accepted: 25-12-2020 / Doi: https://doi.org/10.32923/sci.v5i1.1391

\begin{abstract}
ABSTRAK
Sepak terjang gerakan Muhammadiyah di Indonesia telah berlangsung sebelum masa kemerdekaan bangsa Indonesia. Hingga hari ini telah berkontribusi banyak dalam memajukan bangsa ini dengan dakwah di berbagai lini kehidupan, salah satunya pada aspek pendidikan. Penelitian ini bertujuan untuk mengidentifikasi dan mendeskripsikan rambu-rambu bimbingan dan konseling Islami dalam buku Himpunan Putusan Tarjih Muhammadiyah. Pada penelitian ini pula digunakan metode riset kualitatif dengan varian analisis hermeneutika bersusun dan pengujian kabsahan data ditempuh melalui teknik triangulasi sumber data, metode dan peer review. Hasil penelitian ditemukan sejumlah rambu-rambu dalam penyelengaraan bimbingan dan konseling Islami di antaranya: berawal dari wold view konselor muslim; grooming konselor muslim; dan rambu-rambu layanan bimbingan dan konseling Islami. Wold view konselor muslim ditemukan pada kitab masalah lima yang menyoal tentang agama, dunia, sabilillah, ibadah, dan qiyas. Grooming konselor muslim ditemukan batasan pada berpakaian, batasan aurat dan larangan memakai cincin emas. Adapun rambu-rambu layanan bimbingan dan konseling Islami perlu memperhatikan batasan pemajangan gambar dalam ruang BK, penggunaan musik, tidak berkhalwat dengan lawan jenis, penggunaan hijab, hingga batasan penerapan teknik sandiwara (sosiopsiko drama) dalam layanan $B K$.
\end{abstract}

\section{Keywords: worldview, grooming, layanan, konselor, muhammadiyah}

\section{Pendahuluan}

Muhammadiyah sebagai sebuah gerakan dimulai dari ide dan konsep dakwah yang diusung oleh pendirinya yakni Muhammad Darwis atau dikenal dengan K.H. Ahmad Dahlan. Dalam perjalanan bangsa Indonesia, gerakan dakwah Muhammadiyah tidak lagi diragukan nasionalismenya dalam membangun dan memajukan umat dan bangsa. Sejarah mencatatkan ungkapan salah seorang kader Muhammadiyah pada pertemuan akbar Muhammadiyah pada 18 Juni 1920, yakni Soedjak dengan tuturan "hum rijal wa nahnu rijal," artinya: "mereka lelaki dan kita juga lelaki". Maknanya adalah sebuah ungkapan yang lahir dari motivasi, tekad dan cita-cita melangit untuk membangun peradaban Islam di Indonesia.

Sejatinya, dari awal KH. Ahmad Dahlan telah memiliki kepekaan terhadap fenomena bangsa Indonesia, utamanya umat Islam yang cenderung stagnan, dengan pola pikirnya yang jumud. Untuk itu, beliau berpikir bahwa salah satu cara untuk mengembangkan pola pikir umat Islam di Indonesia agar dinamis dan berkemajuan, maka diperlukan suatu upaya pergerakan di bidang pendidikan. ${ }^{2}$ Nashir sendiri juga menyebutkan bahwa pada hakikatnya Muhammadiyah merupakan gerakan pembaruan atau gerakan tajdid, salah satunya dirintis melalui gerakan di bidang pendidikan. ${ }^{3}$ Dengan demikian, dipahami bahwa gerakan pendidikan tersebut tidak dapat terlepas dari sistem keyakinan dalam agama Islam, yang termuat pada Al-Qur'an dan Al-Hadis sebagai pondasi dalam gerakan pembaruan di Indonesia.

\footnotetext{
${ }^{1}$ Yuristiadi, G., "Aktivisme Hoofdbestuur Muhammadiyah Bagian PKO di Yogyakarta Sebagai Representasi Gerakan Pelayanan Sosial Masyarakat Sipil (1920-1931)”, Afkaruna: Indonesian Interdisciplinary Journal of Islamic Studies 11, no. 2 (2015): h. 199.

${ }^{2}$ Tahir, G., "Muhammadiyah (Gerakan Sosial Keagamaan dan Pendidikan)", Jurnal Adabiyah 10, no. 2 (2010): h. 163.

${ }^{3}$ Nashir, H., Muhammadiyah Gerakan Pembaruan (Yogyakarta: Suara Muhammadiyah, 2010), h. 1-2.
} 
Pendidikan, pada definisinya ialah merupakan suatu pengondisian yang terencana, tersistematis dan proses pengubahan tingkah laku dan sikap individu atau sekelompok individu ke arah pendewasaaan manusia melalui usaha pelatihan dan pengajaran. ${ }^{4}$ Sementara itu, pada praksisnya, melalui hasil penelitian Ali, dkk., konsep pendidikan Islam KH. Ahmad Dahlan merujuk pada: 1) pondasi pendidikan berkemajuan, dalam mana agama berinteraksi secara dialektis dengan problematika kehidupan sosial; 2) akal dan pengamalan serta berkemajuan (progresif) adalah tiga dimensi pendidikan berkemajuan; 3) jiwa progresif religius adalah dasar falsafah pendidikan K.H. Ahmad Dahlan; dan 4) penghargaan terhadap akal dan upaya menumbuh-kembangkan akal (kecerdasan) adalah bentuk pendidikan berkemajuan berlandaskan agama dan kehidupan sosial. ${ }^{5}$ Dengan demikian, konsep pendidikan pada kultur Muhammadiyah tampak mengekspektasikan pendidikan yang sarat akan upaya pengembangan akal (kecerdasan) berbasis muatan nilai-nilai Islam yang secara aplikatif dapat adaptif dan progresif terhadap situasi dan perkembangan kehidupan sosial masyarakat.

Dalam sebuah institusi pendidikan, pada praksisnya, salah satu hal yang tidak dapat terpisahkan adalah unsur bimbingan dan konseling, di samping unsur kepemimpinan (kepala sekolah), manajemen/administrasi, dan pembelajaran sekolah. Adapun ekspektasi kinerja dan ranah tugas konselor pada satuan pendidikan formal disajikan dalam gambar di bawah ini:

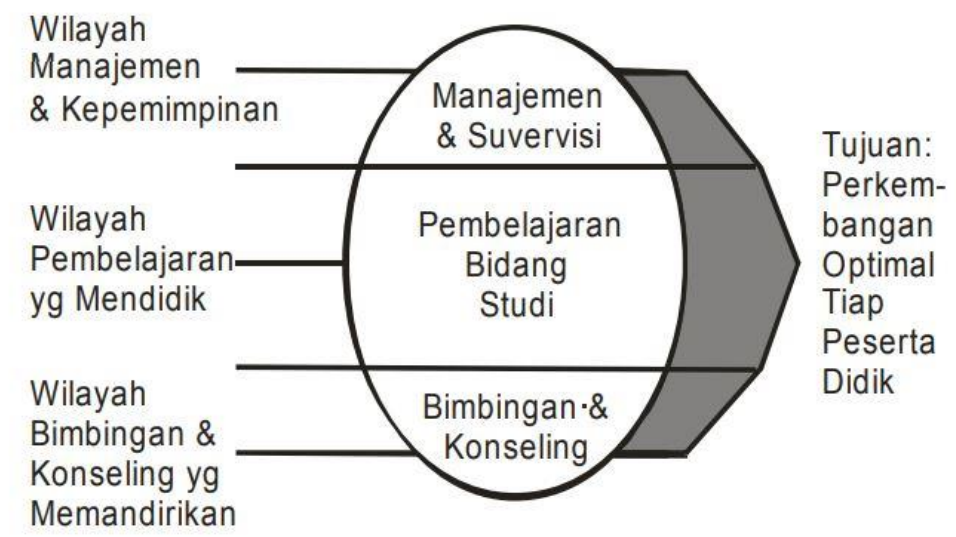

Gambar 1.1. Ranah Pelayanan BK di Sekolah. ${ }^{6}$

Kendati demikian, bila mengacu pada pemaknaan gambar di atas, maka muncul persoalan baru tatkala posisi guru BK dan layanannya berada pada satuan pendidikan yang memiliki kultur khas. Salah satunya pada orientasi pengembangan peserta didik di bawah naungan organisasi masyarakat Muhammadiyah. Tentulah memiliki prinsip tersendiri, namun tetap sejalan dengan aturan pemerintah, tepatnya pada pasal 55 dari UU RI No. 20 Tahun 2003, yang memperbolehkan penyelenggaraan pendidikan formal sesuai dengan kekhasan agama, budaya dan lingkungan sosial. ${ }^{7}$ Sehubungan dengan itu, organisasi Muhammadiyah, dari kebijakan tersebut, maka diperbolehkan merumuskan konsep pendidikan khas untuk tujuan pengembangan optimal peserta didik, salah satunya melalui perumusan rambu-rambu bimbingan dan konseling Islam. Adapun perumusan itu dapat digali melalui buku Himpunan Putusan Tarjih Muhammadiyah. ${ }^{8}$

\section{Metode Penelitian}

Dalam penelitian ini digunakan metode riset kualitatif bertipe hermeneutika, tepatnya varian analisis hermeneutika bersusun (AHB). AHB pada dasarnya merupakan penelitian yang sifatnya refleksif (penafsiran atas penafsiran), ${ }^{9}$

\footnotetext{
${ }^{4}$ https://kbbi.kemdikbud.go.id/entri/pendidikan (Diakses tanggal 12 Agustus 2020).

${ }^{5}$ Ali, M., Kuntoro, S. A., \& Sutrisno, S., "Pendidikan Berkemajuan: Refleksi Praksis Pendidikan KH Ahmad Dahlan", Jurnal Pembangunan Pendidikan: Fondasi dan Aplikasi 4, no. 1 (2016).

${ }^{6}$ Nasional, D. P., Rambu-Rambu Penyelenggaraan Bimbingan dan Konseling dalam Jalur Pendidikan Formal (Jakarta: Direktorat Jenderal Peningkatan Mutu Pendidikan dan Tenaga Kependidikan Departemen Pendidikan Nasional, 2008)

${ }^{7}$ Indonesia, P. R., Undang-undang Republik Indonesia nomor 20 tahun 2003 tentang Sistem Pendidikan Nasional (Jakarta: Pemerintah Republik Indonesia, 2003).

${ }^{8}$ Muhammadiyah, P. P., Himpunan Putusan Tarjih Muhammadiyah (Yogyakarta: Suara Muhammadiyah, 2011).

${ }^{9}$ Mappiare, A., Tipe-tipe metode riset kualitatif untuk eksplanasi sosial budaya dan bimbingan konseling. (Malang: Elang Mas bersama Prodi Bimbingan dan Konseling Fakultas Ilmu Pendidikan Universitas Negeri Malang, 2013).
} 
berangkat dari penafsiran atas teks ke konteks (lapangan) dan atau sebaliknya. ${ }^{10}$ Hal ini dimaksudkan untuk mengkompromikan dan mendiskusikan data antara teks dan lapangan, tepatnya untuk memperoleh pemaknaan, "understanding of underlying meaning." ${ }^{11}$ Data teks difokuskan pada buku Himpunan Putusan Tarjih Muhammadiyah. Sementara data lapangan diperoleh melalui wawancara terhadap key informant yakni stake holders pimpinan Muhammadiyah di Sulawesi Selatan. Di antara kedua data tersebut kemudian dianalisis dengan kompromi teoritik yang relevan, pengarusutamaannya pada pendekatan bimbingan dan konseling Islami. Untuk menguji keabsahan data dalam memperoleh pengetahuan dan kebenaran yang handal, maka diterapkan triangulasi metode, peer review, dan sumber data. Triangulasi sumber data yaitu dengan membandingkan antara teks HPT Muhammadiyah dengan sejumlah naskah, literatur dan artikel hasil penelitian yang relevan. Triangulasi metode dengan membandingkan antara metode wawancara dan interpretasi teks. Adapun triangulasi peer review adalah dengan membandingkan atau mengkonfirmasi pandangan antara ahli agama atau stakeholders Muhammadiyah dengan ahli bimbingan dan konseling.

\section{Diskusi dan Pembahasan}

Pada penelitian ini ditemukan 3 (tiga) rambu-rambu konselor muslim dalam HPT Muhammadiyah yaitu world view konselor muslim, grooming konselor muslim dan rambu-rambu dalam layanan bimbingan dan konseling Islam. Masingmasing memiliki derivatnya tersendiri. Kitab masalah lima yakni agama, dunia, ibadah, sabilillah dan qiyas adalah merupakan kerangka world view konselor muslim. Pengaturan penggunaan cincin dan batasan aurat adalah bagian dari grooming konselor muslim yang mesti diperhatikan. Sementara pengaturan penggunaan musik, hijab/sitar, dan penerapan bermain peran/sandiwara adalah bagian dari rambu-rambu dalam layanan bimbingan dan konseling Islam.

\section{World View Konselor Muslim}

Dalam buku Himpunan Putusan Tarjih (HPT) diperoleh gambaran world view konselor muslim pada konsep kitab masalah lima yakni agama, dunia, ibadah, sabilillah dan qiyas. Agama ialah ajaran Islam yang diturunkan oleh Allah Ta'ala dan dibawa oleh Rasulullah saw. berupa petunjuk dan larangan yang harus dipedomani oleh umat manusia demi kemaslahatan kehidupan dunia dan akhiratnya, yang semuanya telah sempurna disebutkan dalam Al-Qur'an dan Sunah yang sahih. ${ }^{12}$

Dunia yakni yang ditujukan pada "urusan dunia" sebagaimana Nabi saw. bersabda: "Kamu lebih mengerti urusan duniamu". Semua urusan atau persoalan keduniawian yang tidak ada sangkut pautnya terhadap hikmah diutusnya Rasulullah saw., sehingga sepenuhnya diserahkan kepada keahlian dan potensi alamiah manusia dalam upaya pengembangan taraf kehidupannya. ${ }^{13}$

Ibadah ialah segala aktivitas yang ditujukan kepada Allah Ta'ala sebagai upaya mendekatkan diri kepada-Nya (taqarrub Ilallah), mematuhi segala perintah-Nya, dan menjauhi segala larangan-Nya; Ibadah terbagi dua, khusus dan umum; ibadah khusus yakni semua bentuk ibadah yang telah ditetapkan beserta perinciannya oleh Allah Ta'ala, melingkupi tata cara dan aturan-aturannya; sementara ibadah umum yakni semua bentuk aktivitas ibadah yang diridai oleh Allah Ta'ala. ${ }^{14}$

Sabilillah ialah jalan yang menyampaikan kepada keridaan Allah, berupa segala amalan yang diizinkan Allah untuk memuliakan kalimat (agama)-Nya dan melaksanakan hukum-hukum-Nya. ${ }^{15}$

Qiyas ialah salah satu dasar mutlak dalam berhukum Islam, setelah Al-Qur'an, Al-Hadis dan Ijmak; Qiyas diperlukan untuk memperkuat dan menarik kesimpulan hukum Islam bilamana menghadapi persoalan-persoalan yang dihajatkan untuk diamalkan dalam kehidupan umat muslim; adapun Qiyas dipergunakan manakala dalil dari Al-Qur'an dan Al-Hadis tidak ditemukan dalam beristinbat (menarik kesimpulan hukum Islam) sehingga dibutuhkan ijtihad melalui nas-nas yang ada beserta persamaan ilat yang diterapkan oleh ulama-ulama salaf dan khalaf.. ${ }^{16}$

Berdasarkan hasil wawancara, subjek terteliti SH-B ihwal "konsep kitab masalah lima", beliau bertutur bahwa: "Dalam kalangan umat Islam di Indonesia, khususnya di Muhammadiyah, dikenal istilah 'Masalah Lima' yang menjadi bahasan yang penuh dengan makna sejarah atau secara historiografis menyangkut perkembangan Muhammadiyah sampai saat ini. Kitab ini merupakan rumusan awal tentang Islam menurut pandangan Muhammadiyah. Penyusunan

\footnotetext{
${ }^{10}$ Aswar, A., Mappiare-At, A., \& Ramli, M., “Identifikasi Teknik-teknik Pengubahan Tingkah Laku dalam Penerapan Pemikiran Ibnu Qoyyim Al-jauziyyah untuk Pengentasan Korban Seks Bebas dan Homoseks (Kajian Analisis Hermeneutika Bersusun)", Jurnal Pendidikan: Teori, Penelitian, dan Pengembangan 1, no. 2 (2016).

${ }^{11}$ Alvesson, M., \& Sköldberg, K., Reflexive Methodology: New Vistas for Qualitative Research (London: Sage, 2017).

${ }^{12}$ Muhammadiyah, P. P. (2011). Himpunan Putusan Tarjih Muhammadiyah. Yogyakarta: Suara Muhammadiyah.

${ }^{13}$ Ibid.

${ }^{14}$ Ibid.

${ }^{15}$ Ibid.

${ }^{16}$ Ibid.
} 
kitab ini jelas rujukannya yaitu dari Al-Qur'an maupun As-Sunnah. Di dalam rumusan tersebut tercantum pandangan dasar tentang Islam menurut pandangan Muhammadiyah, yaitu agama, dunia, ibadah, sabilillah, dan qiyas."17

Pada teks buku HPT dan pandangan SH-B di atas, dapat ditarik makna bahwa seorang imawan (kader Muhammadiyah) seyogianya mesti memiliki wold view dalam berperilaku keseharian, tidak terkecuali konselor muslim. Penguasaan dan pemahaman akan masalah lima ini, yakni agama, dunia, ibadah, sabilillah, dan qiyas adalah world view yang harus melekat pada pribadi konselor muslim, terlebih lagi seorang kader Muhammadiyah, dalam berpikir, berperasaan, dan bertindak selama melakukan khidmat kepada umat dan bangsa, tidak terkecuali dalam layanan bimbingan konseling Islam. Anwar mengatakan bahwasanya kekhasan bimbingan konseling Islam terletak pada spiritmoralitasnya, yakni pada proses penyelenggaraannya yang berorientasi pada tuntunan Al-Qur'an dan Al-Hadis. ${ }^{18}$ Hal ini diperkuat lagi oleh hasil penelitian Hamjah dan Akhir yang menyebutkan bahwa konsep akidah, ibadah, dan akhlak adalah tiga aspek yang perlu dikelola dalam layanan konseling Islami. ${ }^{19}$ Untuk itu, orientasi pengubahan perilaku konseli dalam bimbingan dan konseling Islam difokuskan dan dititikberatkan pada tiga domain tersebut, yakni akidah, ibadah, dan akhlak, tentulah dengan disertai penguasaan world view pada konsep "kitab masalah lima" yang memadai oleh konselornya.

Konsep wold view dalam dunia layanan bimbingan konseling telah menjadi bagian penting dari pembahasan konseling multikultural. Hal ini ditengarai oleh pertimbangan budaya dalam proses pelayanan konseling, sehingga membutukan keahlian, alih-alih kompetensi konselor multibudaya, agar dapat adaptif struktur, atas dan bawah dengan unsur pimpinan serta sistem yang berlaku. Salah satunya konselor dituntut untuk memahami atau memiliki wawasan (knowledge) atau kesadaran budaya akan orientasi sebuah institusi pendidikan formal dengan kultur yang khas, tidak terkecuali pada institusi pendidikan di bawah naungan Muhammadiyah. Ibrahim \& Dykeman mengartikulasikan world view sebagai "a central construct of cultural identity and pertains to the beliefs, values, and assumptions that a client has as a result of the socialization process." 20 Dari pengertian tersebut, dipahami bahwa world view adalah merupakan konstruksi identitas kultural seseorang atas keyakinan, nilai, dan prinsip hidup yang dipeganginya. Dengan tegasnya, Ivey, Ivey, \& Zalaquett pun menyatakan bahwa keberagaman wold view tiap individu pada dasarnya disebabkan dan dipengaruhi oleh latar belakang sejarah, agama, dan budaya yang berbeda, sehingga mereka sering kali memiliki pandangan filosofis yang sangat berbeda tentang makna hidup, benar dan salah, serta tanggung jawab pribadi." ${ }^{21}$ Untuk itu, seorang imawan (kader Muhammadiyah) dan atau konselor muslim mesti memahami dengan baik "konsep kitab masalah lima" sebagai konsep wold view-nya dalam melakukan aksi layanan bimbingan dan konseling Islam di institusi pendidikan Muhammadiyah.

\section{Grooming Konselor Muslim}

Dalam buku Himpunan Putusan Tarjih (HPT) diperoleh gambaran grooming konselor muslim mulai dari batasan berpakaian, batasan aurat, hingga batasan menggunakan perhiasan (cincin). Batasan berpakaian dalam HPT disebutkan dengan merujuk hadis Nabi saw. bahwa haram hukumnya bagi pria memakai emas, hal ini dengan melihat hadis Rasulullah yang berbunyi: "Dihalalkan emas dan sutera bagi kaum wanita dari umatku dan diharamkan kepada kaum prianya." (HR. Tirmidzi, Nasai dan Ahmad). ${ }^{22}$

Sementara batasan aurat memiliki tiga ketentuan yakni: (1) Aurat bagi lelaki yaitu di antara pusat dan lutut. Hal ini dengan melihat hadis dari Ayyub, bahwa Nabi saw. bersabda: "Aurat orang lelaki itu antara pusat dan lutut." (HR. Baihaqi dan Daraquthni); (2) Aurat lelaki juga termasuk paha. Hal ini juga ditilik berdasarkan hadis dari Ibnu 'Abbas, Jurhud dan Muhammad bin Jahys, dari Rasulullah saw. bersabda: "Paha itu aurat." (HR. Bukhari); (3) Hendaknya memakai celana pandu Hizbul Wathan untuk menutupi aurat lelaki demi menjaga keseragaman dalam kalangan Muhammadiyah. ${ }^{23}$

Adapun batasan penggunaan perhiasan (cincin) ialah dibatasi dengan menggunakan cincin berbahan dasar perak, maka mubah hukumnya. Hal ini disebabkan oleh adanya hadis dari Anas bahwa Rasulullah saw. diberitahu oleh sahabatnya tatkala menulis surat bahwasanya mereka tidak menyukai membaca surat ketika belum distempel (dicap), sehingga beliau kemudian membuat cincin berbahan dasar perak lalu diukirnya "Muhammad Rasulullah", lalu bersabda kepada khalayak: "Sesungguhnya kami membuat cincin dari perak yang kami ukir "Muhammad Rasulullah," maka

\footnotetext{
${ }^{17}$ Wawancara dilaksanakan pada hari Jumat/ 3 Juli 2020, pukul 09.00 Wita.

${ }^{18}$ Anwar, M. F., Landasan Bimbingan dan Konseling Islam. (Yogyakarta: Deepublish, 2019).

${ }^{19}$ Hamjah, S. H., \& Akhir, N. S. M., "Islamic approach in counseling”, Journal of religion and health 53, no. 1 (2014).

${ }^{20}$ Ibrahim, F. A., \& Dykeman, C., "Counseling Muslim Americans: Cultural and spiritual assessments”, Journal of Counseling \& Development 89, no. 4 (2011).

${ }^{21}$ Ivey, A. E., Ivey, M. B., \& Zalaquett, C. P., Intentional Interviewing and Counseling: Facilitating Client Development in a Multicultural Society, 9th Edition (Boston: Cenggage Learning, 2018), h. 39.

${ }^{22}$ Muhammadiyah, P. P., Himpunan Putusan Tarjih Muhammadiyah (Yogyakarta: Suara Muhammadiyah, 2011).

${ }^{23}$ Ibid.
} 
janganlah ada seseorang yang mengukir seperti ukiran itu." Terdapat pula riwayat lainnya, bahwa Nabi saw. memakai cincin perak pada tangan kanannya, yang mana permata cincinnya itu dari Habsyi, dan permata tersebut dihadapkan ke arah telapak tangan beliau, (Lima ahli Hadis meriwayatkan hadis ini). ${ }^{24}$

Berdasarkan hasil wawancara, subjek terteliti SH-B ihwal batasan berpakaian, batasan aurat, beliau bertutur bahwa: "Aurat merupakan bagian-bagian dari anggota tubuh manusia yang hukumnya adalah wajib ditutupi dari pandangan orang lain, yaitu dengan dikenakannya pakaian. Memperlihatkan aurat bagi seorang muslim, maka itu dianggap sesuatu yang melanggar syariat dan berdosa. Penjelasan mengenai hal tersebut sangat jelas dalam surah An-Nuur ayat 31. Adapun batasan menggunakan perhiasan (cincin), subjek terteliti SH-B kembali bertutur bahwa: Dalam hadis Nabi, telah diberitakan tentang pelarangan bagi kaum laki-laki memakai cincin emas. Hukum asalnya, memakai cincin tidaklah terlarang kecuali jika disertai dengan i'tiqad, maksud atau keyakinan tertentu. Apalagi bahannya emas, emas bagi perempuan diperbolehkan, namun dilarang bagi kaum laki-laki, sebagaimana dalam hadis Nabi saw. bersabda: "Dihalalkan emas dan sutera bagi perempuan-perempuan dari umatku; dan diharamkannya atas laki-laki dari umatku." "25

Pada teks buku HPT dan konfirmasi pandangan subjektif SH-B di atas, maka seyogianya para kader Muhammadiyah dan atau konselor muslim agar dapat memperhatikan etika grooming-nya dalam aksi layanan bimbingan dan konseling Islam. Untuk batasan aurat dalam berpakaian, maka ditekankan bagi laki-laki menutupi pusat hingga lutut. Pada penggunaan cincin, maka ditekankan bagi laki-laki untuk tidak menggunakan cincin yang terbuat dari bahan emas. Sementara bagi perempuan etika grooming-nya mesti berpanduan pada perintah Qur'an surah An-Nuur ayat 31. Adapun grooming sendiri oleh Aswar, Iskandar dan Nur diartikulasikan sebagai sebuah kebiasaan diri dalam berdandan, berpenampilan, dan berpakaian dengan tujuan agar citra diri tampak lebih indah atau rapi. ${ }^{26}$

Berdasarkan hasil penelitian ini, maka grooming konselor muslim dapat didefinisikan sebagai suatu tradisi dan etika seorang muslim dalam berpenampilan, berpakaian dan berdandan agar tampak lebih indah, rapi dan sopan dalam menyelenggarakan bimbingan dan konseling Islam. Segayut dengan ini pula, Aswar, Iskandar dan Nur melalui penelitiannya berhasil mengidentifikasi model rambut, model pakaian, model sorban (songkok), model sarung (celana), model alas kaki, model perhiasan, hingga model wewangian Nabi Muhammad saw., sebagai entitas pada grooming konselor muslim dalam kajiannya atas kitab Asy-Syama'il Al-Muhammadiyah. ${ }^{27}$ Dengan demikian, maka dapat dipahami bahwa seyogianya konselor muslim pada dasarnya mesti mematuhi rambu-rambu dan atau memiliki panduan grooming mulai dari ujung kaki hingga ke ujung rambut dengan berpatokan pada Kitabullah dan Sunah Nabi saw.

\section{Rambu-Rambu Layanan Bimbingan Konseling Islam}

Dalam buku Himpunan Putusan Tarjih (HPT) diperoleh gambaran ihwal batasan pemajangan gambar dalam ruangan $\mathrm{BK}$, batasan penggunaan musik, tidak berkhalwat, batasan penggunaan hijab, dan batasan penerapan sandiwara dalam layanan BK. Batasan pemajangan gambar dalam ruangan bimbingan dan konseling, hukumnya berkisar kepada ilatnya (sebabnya) dalam mana terdapat tiga macam: Pertama, perihal penyembahan, maka haram hukumnya; Kedua, perihal media pembelajaran dan atau pengajaran, maka mubah hukumnya; dan Ketiga, perihal perhiasan ruangan, maka ada 2 ketentuan: (1) tidak dikhawatirkan untuk mendatangkan fitnah, maka mubah hukumnya; (2) jika dapat mendatangkan fitnah, maka ditinjau 2 syarat: jika mengarah kepada fitnah yang sifatnya ma shiyat, maka makruh hukumnya, dan jika mengarah kepada fitnah kemusyrikan, maka haram hukumnya berupa pemajangan gambar-gambar orang salah dan Nabi. ${ }^{28}$

Berdasarkan hasil wawancara, subjek terteliti SH-A ihwal batasan pemajangan gambar dalam ruangan BK, beliau bertutur bahwa: "Kalau untuk keperluan pembelajaran, pembinaan, dan penguatan tentang penanaman nilai moral dan akhlak, memajang gambar dalam ruang belajar tidak menjadi sebuah masalah, dengan catatan gambar tersebut tidak bertentangan dengan nilai syar'i, norma kesopanan dalam masyarakat, dan peraturan pemerintah. Jadi ada tiga hal yang harus diperhatikan dalam memajang gambar. Pertama, tidak melanggar syar'i atau agama, misalnya gambargambar kemusyrikan, pemujaan pada selain Allah, dll. Kedua tidak melanggar norma kemasyarakatan, misalnya gambar-gambar yang menampilkan ketidaksopanan, dll. Yang ketiga tidak mengandung unsur mendiskreditkan pemerintah atau bersifat provokasi untuk melawan pemerintah.,"29

Pada teks buku HPT dan konfirmasi pandangan subjektif SH-A di atas, maka seyogianya para kader

\footnotetext{
${ }^{24}$ Ibid.

${ }^{25}$ Wawancara dilaksanakan pada hari Jumat/ 3 Juli 2020, pukul 09.00 Wita.

${ }^{26}$ Aswar, A. I., \& Nur, E. W., "Grooming Konselor Muslim: Panduan Berpenampilan Dalam Kitab Asy-Syama'il AlMuhammadiyah", Jurnal Bimbingan dan Konseling Islam 10, no. 01 (2020).

${ }^{27}$ Ibid.

${ }^{28}$ Muhammadiyah, P. P., Himpunan Putusan Tarjih Muhammadiyah (Yogyakarta: Suara Muhammadiyah, 2011).

${ }^{29}$ Wawancara dilaksanakan pada hari Jumat/ 26 Juni 2020, pukul 15.50 Wita.
} 
Muhammadiyah dan atau konselor muslim agar dapat memperhatikan batasan pemajangan gambar sebagai salah satu rambu-rambu dalam pemberian pelayanan bimbingan konseling Islami. Secara umum, dalam ruang BK, sering dijumpai pemajangan foto tokoh-tokoh konseling Barat, semisal foto Sigmund Freud, CR. Rogers, BF. Skinner, hingga Albert Ellis, yang notabanenya adalah merupakan orang kafir (non muslim). Dengan demikian, bila ditarik dalam konteks hasil penelitian ini, maka perkara tersebut termasuk dari bagian mengidolakan orang kafir, ghuluw (melampaui batas), ${ }^{30}$ dan juga perbuatan israf (berlebihan), ${ }^{31}$ sehingga hal ini tidak patut dalam Islam.

Senada dengannya, dalam penelitian Hidayati dan Saputro, ditemukan ungkapan subjek terteliti lapangannya bertutur bahwa "muslim yang mengidolakan bintang film drama Korea adalah muslim KTP, yang jelas dilarang dalam Al-Qur'an." ${ }^{32}$ Hal tersebut menunjukkan identitas diri yang utuh dan memadai sebagai seorang muslim yang memiliki izzah (kemuliaan) terhadap agamanya. Untuk itu, ekspektasi konselor muslim pun demikian dalam hal pemberian layanan bimbingan dan konseling Islami ialah dengan menunjukkan izzah-nya. Tidak terkecuali dengan menjauhi mengidolakan dan memajang foto orang kafir, tidak memajang gambar yang berunsur kesyirikan, ketidaksopanan, serta gambar mengandung unsur melawan pemerintah, sebagaimana tafsiran subjektif terteliti SH-A.

Pada bahasan batasan penggunaan musik dalam bimbingan dan konseling, dalam teks buku HPT, ditemukan konsep “Alatul Malahi”, perihal yang dimaksud ialah alat musik (bunyi-bunyian), maka penetapan hukumnya merujuk pada sebabnya (ilatnya), dengannya terdapat 3 ketentuan, yakni: (1) Hukumnya sunah bila penggunaannya memiliki maslahat atau keutamaan di mana dapat berpengaruh kepada motivasi atau keberanian di medan perang; (2) Hukumnya makruh bila tak mendatangkan apa-apa terlebih dipergunakan untuk main-main belaka, hal ini dengan melihat hadis yang berbunyi, "Termasuk kesempurnaan seseorang ialah meninggalkan barang yang tak berarti." (HR. Tirmidzi dari jalur Abu Hurairah); dan (3) Hukumnya haram bila mengarah kepada ma 'siyat (kemaksiatan). ${ }^{33}$

Berdasarkan hasil wawancara, subjek terteliti SH-A ihwal batasan penggunaan musik dalam layanan BK, beliau bertutur bahwa: "Memang, kebanyakan ulama khususnya yang berkecimpung di bidang hukum, mengharamkan musik. Contohnya, Imam Syafi'i menegaskan bahwa diharamkan permainan dengan alat musik dan bahwa tertolak kesaksian seorang yang memiliki budak wanita kemudian mengumpulkan orang mendengar nyanyiannya. Imam Abu Hanifah memandang bahwa mendengar nyanyian termasuk dosa. Sedangkan Imam al-Ghazali secara tegas membolehkan musik. Saya pribadi beranggapan bahwa musik dalam pengajaran bukanlah sesuatu yang urgen, artinya proses pengajaran dapat berhasil meskipun tanpa musik." 34

Pada teks buku HPT dan konfirmasi pandangan subjektif SH-A di atas, maka seyogianya seorang konselor muslim agar dapat memperhatikan batasan penggunaan musik sebagai salah satu rambu-rambu dalam pemberian layanan bimbingan dan konseling Islami. Musik pada umumnya diharamkan oleh mayoritas ulama sebagaimana pandangan subjek terteliti SH-A, demikian pula pada teks buku HPT, meskipun dibolehkan dalam kondisi perang untuk memantik keberanian para prajurit. Jika penyelenggaraan layanan bimbingan dan konseling tidaklah begitu urgen dengan penggunaan musik, apatah lagi hanya membuat lalai dari berdzikir kepada Allah, maka sebaiknya ditinggalkan.

Sejatinya berbagai penelitian menunjukkan keefektifan penggunaan musik dalam penyelenggaraan layanan BK itu sendiri. Di antaranya penelitian yang dilakukan oleh Sutisna dan Tadjri dengan memakai bantuan musik klasik Jawa pada penerapan intervensi konseling kelompok behavioral dengan teknik desentisisasi sistematisnya, telah teruji efektif dalam mereduksi communication apprehension siswa SMA 1 Puri Mojokerto. ${ }^{35}$ Sama halnya pada penelitian yang dilaksanakan oleh Situmorang, Mulawarman, dan Wibowo berkenaan intervensi konseling kelompok pendekatan CBT dengan bantuan terapi musik, telah teruji efektif dalam mengurangi kecemasan akademik mahasiswa milenial BK Unika Atma Jaya. ${ }^{36}$ Adapun beberapa artikel ilmiah juga menunjukkan bahwa pada dasarnya murattal Al-Qur'an, ${ }^{37}$ dan juga

\footnotetext{
${ }^{30}$ Dahlan, F., "Fundamentalisme Agama: Antara Fenomena Dakwah dan Kekerasan Atas Nama Agama", Ilmu Dakwah: Academic Journal for Homiletic Studies 6, no. 2 (2012).

${ }^{31}$ Afrina, D., "Rasionalitas Muslim terhadap Perilaku Israf dalam Konsumsi Perspektif Ekonomi Islam", EkBis: Jurnal Ekonomi dan Bisnis 2, no. 1 (2019).

${ }^{32}$ Hidayati, O. N., \& Saputro, M. E., "Korean Drama Constructing Multiculturalism Among Muslim Women Students”, $A L-A L B A B$ 6, no. 1 (2017).

${ }^{33}$ Muhammadiyah, P. P., Himpunan Putusan Tarjih Muhammadiyah (Yogyakarta: Suara Muhammadiyah, 2011).

${ }^{34}$ Wawancara dilaksanakan pada hari Jumat/ 26 Juni 2020, pukul 15.50 Wita.

${ }^{35}$ Sutisna, Y., \& Tadjri, I., "Keefektifan Konseling Kelompok Behavioral Teknik Systematic Desensitization Berbantuan Musik Klasik Jawa untuk Mereduksi Communication Apprehension”, Jurnal Bimbingan Konseling 5 no. 1 (2016).

${ }^{36}$ Situmorang, D. D. B., Mulawarman, M., \& Wibowo, M. E., "Comparison of the Effectiveness of CBT Group Counseling with Passive vs Active Music Therapy to Reduce Millennials Academic Anxiety”, International Journal of Psychology and Educational Studies 5, no. 3 (2018).

${ }^{37}$ Tambunan, S., "Seni Islam Terapi Murattal Alquran Sebagai Pendekatan Konseling Untuk Mengatasi Kecemasan”, Al-Mishbah: Jurnal Ilmu Dakwah dan Komunikasi 14, no. 1 (2018).
} 
Ruqyah Syar'iyyah ${ }^{38}$ dapat dijadikan sebagai alternatif pendekatan interventif dalam praktik konseling Islami. ${ }^{39}$ Dengan demikian, dapat dipahami bahwa seni musik dapat berkontribusi efektif pada penyelenggaraan konseling, namun pada buku HPT, pendapat ulama, dan subjek terteliti SH-A berkecenderungan untuk menjauhinya, apatah lagi bila ada bentuk intervensi konseling yang lebih syar'i, seperti penggunaan murattal Al-Qur'an dan Ruqyah Syar'iyyah sebagai teknik intervensi dalam konseling Islami.

Pada bahasan tidak berkhalwat dalam proses layanan bimbingan dan konseling, dalam teks buku HPT ditemukan narasi bahwa pria mengajar wanita itu boleh, begitu pun sebaliknya. Perihal tersebut merujuk pada hadis riwayat Bukhari dari jalur Abu Sa'id Al-Khudri yang menyatakan bahwasanya kaum wanita berkata kepada Rasulullah saw. bahwa, "Kaum pria telah mengalahkan kami memperoleh waktumu, maka tentukanlah bagi kami (wanita) untuk menghadap engkau." Maka Nabi saw. berjanji kepada kaum wanita itu bahwa suatu hari mereka akan ditemui oleh beliau. Lalu Nabi pun mengajari dan menasehati mereka. Sebagaimana yang disabdakannya bahwa: "Seorang wanita dari kamu yang kematian 3 orang anak, tentu merupakan dinding baginya dari neraka." Mereka pun menyahut: "Jikalau dua?." Jawab Nabi saw.: "Dua pun juga!." Pada riwayat lainnya, dari Abu Sa'id, bahwasanya terdapat seorang wanita yang datang kepada Nabi saw. seraya berkata: "Wahai Rasulullah, kaum pria sering datang mendapat tutur kata engkau, maka tentukanlah hari bagi kami (wanita) untuk mengahadap di mana engkau dapat mengajar kami tentang apa yang telah Allah mengajarkan kepada engkau." Maka dijawab oleh beliau: "Berkumpullah pada hari anu, ditempat anu." Selanjutnya kaum wanita tersebut bergumul dan didatangi oleh Nabi saw. lalu diajarinya mereka tentang apa yang telah Allah swt. ajarkan kepadanya. Adapun jika wanita mengajar pria, maka itu pun diperbolehkan, sebab tidak adanya pelarangan yang mencegah hal demikian; akan tetapi sudah tentu disyaratkan dihadirkannya keamanan, seperti menjaga pandangan, menjaga hati dan tidak menyendiri atau berdua-duaan (berkhalwat). ${ }^{40}$

Adapun secara kontekstual, berdasarkan hasil wawancara, subjek terteliti SH-A ihwal bahasan tidak berkhalwat dalam layanan BK, beliau bertutur bahwa: "Sangat jelas dalam Al-Hadis disebutkan bahwasanya Nabi saw. bersabda: "Janganlah salah seorang dari kalian berkhalwat dengan seorang wanita karena sesungguhnya syaitan menjadi orang ketiga di antara mereka berdua." Oleh sebab itu, tidak ada satu pun alasan yang dapat membenarkan atau membolehkan terjadinya khalwat antara lelaki dan wanita, walau dengan alasan memberikan layanan bimbingan."

Selain itu, subjek terteliti SH-B, ihwal batasan tidak berkhalwat dalam layanan BK, juga bertutur bahwa: "Istilah khalwat berasal dari khulwah dari akar kata khala yang berarti sunyi atau sepi. Sedangkan menurut istilah, khalwat adalah keadaan seseorang yang menyendiri dan jauh dari pandangan orang lain. Larangan khalwat adalah pencegahan dini bagi perbuatan zina. Syariah Islam dengan tegas melarang melakukan zina, sementara khalwat/mesum merupakan washilah atau jalan/ peluang untuk terjadinya zina. Maka harus dijauhi atau tidak boleh dikerjakan." ${ }^{2}$

Pada teks buku HPT dan konfirmasi pandangan subjektif SH-A dan SH-B di atas, maka seyogianya seorang konselor muslim agar dapat memperhatikan rambu-rambu pemberian layanan bimbingan dan konseling dengan lawan jenisnya. Secara tegas, baik subjek terteliti SH-A maupun SH-B tidak membenarkan terjadinya kondisi pemberian layanan bimbingan dan konseling pada keadaan berkhalwat dengan lawan jenis. Namun, pada buku HPT kondisi pemberian pengajaran (transfer of knowledge) dengan lawan jenis adalah diperbolehkan, dengan syarat dan ketentuan yang diberlakukan secara ketat dalam timbangan syariat, yakni memejamkan mata dan tidak berkhalwat. Untuk itu, sama halnya dalam penyelenggaraan bimbingan dan konseling Islam bahwa konselor muslim laki-laki perlu menundukkan pandangannya terhdadap lawan jenis, begitupun sebaliknya.

Hasil penelitian ini juga sejalan dengan simpulan pengkajian oleh Ab Ghani yang menyatakan bahwa pada dasarnya "hablun minannas" di antara pria dan wanita adalah dilarang dalam syariat, tepatnya pada keadaan berkhalwat, namun dalam keadaan yang menghendaki pertimbangan kemaslahatan, darurat, hajat dan adat kebiasaan setempat, maka ia diperbolehkan dengan syarat yaitu dapat menjaga batasan-batasan syariat. ${ }^{43}$ Sama halnya dan mengkhusus pada penelitian Ramdani dan Aswar, dengan subjek terteliti wanita bercadar yang notabanenya dianggap ekslusif, menyatakan bahwa hablun minannas (pergaulan sosial) mereka secara umum menunjukkan dua kondisi pola interaksi

\footnotetext{
${ }^{38}$ Aswar, A., Mappiare-At, A., \& Ramli, M., "Identifikasi Teknik-teknik Pengubahan Tingkah Laku dalam Penerapan Pemikiran Ibnu Qoyyim Al-jauziyyah untuk Pengentasan Korban Seks Bebas dan Homoseks (Kajian Analisis Hermeneutika Bersusun)", Jurnal Pendidikan: Teori, Penelitian, dan Pengembangan 1, no. 2 (2016).

${ }^{40}$ Muhammadiyah, P. P., Himpunan Putusan Tarjih Muhammadiyah (Yogyakarta: Suara Muhammadiyah, 2011).

${ }^{41}$ Wawancara dilaksanakan pada hari Jumat/ 26 Juni 2020, pukul 15.50 Wita.

${ }^{42}$ Wawancara dilaksanakan pada hari Jumat/ 3 Juli 2020, pukul 09.00 Wita.

${ }^{43}$ Ab Ghani, A., "Batas-batas Pergaulan Antara Lelaki dan Perempuan Dalam Masyarakat Islam Kini: Satu Huraian Hukum Islam Semasa", Jurnal Syariah 7, no. 1 (2019).
} 
sosial yaitu interaksi yang sifatnya fleksibel dalam pola-pola tingkah laku dan interaksi yang bersifat terbatas. ${ }^{44}$ Atas kedua penelitian tersebut, dipahami bahwa pada esensinya Islam melarang dan atau mengharamkan keadaan berkhalwat antara laki-laki ajnabi dengan wanita dalam satu bilik ruangan, tidak terkecuali pada ruangan bimbingan dan konseling, dengan pola interaksi yang sifatnya terbatas. Namun, tampak dapat diterapkan multiple counseling bernuansa Islami ${ }^{45}$, di mana dalam satu bilik ruangan, satu orang konselor lelaki melakukan konseling terhadap wanita yang didampingi oleh mahramnya (suaminya, saudara kandung, dan seterusnya).

Pada bahasan penggunaan hijab dalam layanan bimbingan dan konseling Islam, dalam teks buku HPT Muhammadiyah ditemukan argumentasi bahwa penggunaan tabir pada perhelatan atau musyawarah Muhammadiyah, dengan pertimbangan dan ketentuan untuk selalu menahan pandangan itu syariatkan, sebagaimana firman Allah swt.: "Katakanlah kepada orang-orang mukmin (pria) supaya memejamkan penglihatannya dan menjaga farjinya..." Seterusnya ayat, "Dan katakanlah kepada orang-orang mukminat (wanita) supaya memejamkan penglihatannya dan menjaga farjinya...", dan seterusnya pada Qur'an surat An-Nur ayat 30-31, dengannya Majlis Tarjih memutuskan agar kiranya memasang tabir atau sejenisnya di musyawarah dan pertemuan-pertemuan Persyarikatan Muhammadiyah, yang notabenya dihadiri oleh kaum laki-laki dan perempuan, hal ini bertujuan untuk mencegah terjadinya pelanggaran syariat atau sesuatu yang diharamkan dalam agama Islam. ${ }^{46}$

Adapun secara kontekstual, berdasarkan hasil wawancara, subjek terteliti SH-A ihwal bahasan tidak berkhalwat dalam layanan BK, beliau bertutur bahwa: "Dengan menggunakan hijab kita akan menutupi seluruh aurat yang tidak diperbolehkan dilihat orang lain. Menggunakan hijab tidak semata menutupi aurat, melainkan juga untuk menjaga pandangan seorang muslimah agar tetap berprilaku baik sesuai kaidah agama. Yang dimaksud menjaga pandangan di sini adalah bagaimana wanita menjaga akhlaknya untuk tidak melakukan sesuatu yang di luar syariat agama Islam. Maka sangatlah tepat dalam dunia kependidikan diterapkan penggunaan hijab. ${ }^{, 47}$

Selain itu, subjek terteliti SH-B, ihwal penggunaan hijab dalam layanan BK, juga bertutur bahwa: "Hijab dalam Al-Qur'an selalu digunakan dalam konsep pembatas ruang. Berhijab yang sesuai dengan ketentuan syariat yaitu, ketika kita beribadah, gunakan pakaian yang baik, tapi jangan sampai berlebihan. Dan pakaian yang terbaik, yang substantif, sesungguhnya adalah pakaian takwa. Dalam layanan BK, penggunaan hijab juga sangat penting maknanya."48

Pada teks buku HPT dan konfirmasi pandangan subjektif SH-A dan SH-B di atas, maka seyogianya seorang konselor muslim perlu memanfaatkan hijab atau sitar atau dinding pembatas dalam majelis, tidak terkecuali dalam ruangan bimbingan dan konseling. Tujuannya agar dapat menjaga pandangan dalam berkomunikasi pada penyelenggaraan layanan antara konselor pria dan konseli wanita, atau sebaliknya. Segayut pula pada bahasan sebelumnya bahwa keadaan berkhalwat antara pria ajnabi dan wanita dalam Islam adalah suatu hal yang dilarang, namun dalam kondisi darurat diperbolehkan selama tetap memperhatikan rambu-rambu syariat. Dengan demikian, pada penggunaan hijab atau sitar (dinding pembatas) dalam prosesi pemberian layanan bimbingan dan konseling adalah hal yang maslahat untuk menjaga pandangan dalam interaksi antara konselor dan konseling yang berlawanan jenis.

Argumentasi di atas juga sejalan dengan pandangan Muafiah, melalui artikelnya, ia mengemukakan bahwa sistem pendidikan di Indonesia atau pesantren, pada umumnya menerapkan sistem segregasi gender, memisahkan antara santri perempuan dan laki-laki dalam proses pembelajarannya, tujuannya tidak lain agar tidak terjadi pelanggaran agama. ${ }^{49}$ Sama halnya dengan pemisahan bilik antara konselor pria dan konseli wanita, atau sebaliknya adalah semata-mata dimaksudkan agar tidak terjadi pelanggaran syariat. Bila ditarik ke dalam konseling Islam, maka seorang konselor muslim mesti memahami hal demikian, untuk meningkatkan self awareness, knowledge, dan attitude-nya agar mampu beradaptasi pada budaya khas suatu institusi pendidikan seperti konsep pendidikan Muhammadiyah.

Pada bahasan penerapan sandiwara (psiko-sosiodrama) dalam bimbingan dan konseling, dalam teks buku HPT Muhammadiyah ditemukan narasi pada poin ke-17 ihwal mengadakan sandiwara, berbunyi: "Mengingat perundingan tentang hal ini tidak ada penyelesaiannya dan menghargai pendirian masing-masing, baik yang membolehkannya ataupun yang mengaharamkan, maka dengan pemungutan suara (sistem) mufakat memutuskan: 'Terserah pada masingmasing Lajnah Tarjih'. ." 50

Adapun secara kontekstual, berdasarkan hasil wawancara, subjek terteliti SH-A ihwal bahasan mengadakan dalam layanan BK, beliau bertutur bahwa:"Saya kira tidak masalah selama tidak melanggar syariat agama Islam. Dan benar-

\footnotetext{
${ }^{44}$ Ramdani, F., \& Aswar, A., "Hablun Minannas Wanita Bercadar (Studi Fenomenologi Interaksi Sosial Wanita Bercadar di Kecamatan Manggala Makassar)", NUKHBATUL'ULUM: Jurnal Bidang Kajian Islam 6, no. 1 (2020).

${ }^{45}$ Mappiare-AT, A., Meramu Model Konseling Berbasis Budaya Nusantara: KIPAS (Konseling Intensif Progresif Adaptif Struktur) (Malang: Universitas Negeri Malang, 2017), h. 14.

${ }^{46}$ Muhammadiyah, P. P., Himpunan Putusan Tarjih Muhammadiyah (Yogyakarta: Suara Muhammadiyah, 2011).

${ }^{47}$ Wawancara dilaksanakan pada hari Jumat/ 26 Juni 2020, pukul 15.50 Wita.

${ }^{48}$ Wawancara dilaksanakan pada hari Jumat/ 3 Juli 2020, pukul 09.00 Wita.

${ }^{49}$ Muafiah, E., "Pendidikan Perempuan di Pondok Pesantren", Nadwa 7, no. 1 (2013).

${ }^{50}$ Muhammadiyah, P. P., Himpunan Putusan Tarjih Muhammadiyah (Yogyakarta: Suara Muhammadiyah, 2011). 
benar dengan tujuan untuk memberi penguatan dalam berhasilnya tercapai tujuan pemberian layanan bimbingan itu sendiri." ${ }^{51}$ Selain itu, subjek terteliti SH-B, ihwal penggunaan hijab dalam layanan BK, juga bertutur bahwa: "Islam itu adalah agama yang sangat menghormati hasil karya manusia termasuk seni dan drama atau sandiwara. Tetapi harus diingat, dalam konteks ajaran Islam, sebuah hasil karya haruslah bertujuan untuk mendekatkan diri kita kepada Allah Ta'ala." $" 52$

Pada teks buku HPT dan konfirmasi pandangan subjektif terteliti SH-A dan SH-B di atas, maka seyogianya seorang konselor muslim mesti memahami dengan baik bahwa penerapan sandiwara atau drama (psiko-sosiodrama) dalam bimbingan dan konseling adalah bertujuan kemaslahatan dan tidak melanggar syariat serta tidak melalaikan manusia. Penerapan psiko-sosiodrama dalam dunia konseling pertama kali digagas dan dirintis oleh Jacob L. Moreno melalui pencerapan fenomenanya bahwa dunia teater tampak memiliki kontribusi efektif dalam prosesi terapiutik dan atau psikoedukasi terhadap seseorang, ${ }^{53}$ lalu kemudian disusun konsep, metode, tahapan dan instrumentasinya. ${ }^{54}$ Ihwal penelitian pengembangan metode sosiodrama, Hayuni dan Flurentin telah berhasil mengembangkan sebuah panduan sosiodrama bagi siswa SMP guna meningkatkan sikap peduli sosialnya. ${ }^{55}$ Demikian juga halnya dengan Haryati, Wibowo dan Mulawarman telah berhasil mengkonstruksi teknik sosiodrama ke dalam model bimbingan kelompok guna meningkatkan rasa empati peserta didik. ${ }^{56}$ Atas penelitian tersebut, maka konselor muslim di bawah naungan institusi pendidikan Muhammadiyah dapat memakainya selama berorientasi kebermanfaatan dan tidak melanggar syariat.

\section{Kesimpulan}

Penelitian ini bertujuan untuk mengidentifikasi, mencari-temukan dan mendeskripsikan rambu-rambu bimbingan konseling Islam yang diperoleh dari pemaknaan buku HPT (Himpunan Putusan Tarjih) Muhammadiyah, disertai konfirmasi pandangan dari stakeholder Muhammadiyah Kabupaten Barru. Hasil penelitian Hasil penelitian ditemukan sejumlah rambu-rambu dalam penyelengaraan bimbingan dan konseling Islami di antaranya: berawal dari wold view konselor muslim; grooming konselor muslim; dan rambu-rambu layanan bimbingan dan konseling Islami. Wold view konselor muslim ditemukan pada kitab masalah lima yang menyoal tentang agama, dunia, sabilillah, ibadah, dan qiyas. Grooming konselor muslim ditemukan batasan pada berpakaian, batasan aurat dan larangan memakai cincin emas. Adapun rambu-rambu layanan bimbingan dan konseling Islami perlu memperhatikan batasan pemajangan gambar dalam ruang BK, penggunaan musik, tidak berkhalwat dengan lawan jenis, perhatian terhadap penggunaan hijab atau sitar, hingga batasan penerapan teknik sandiwara (sosio-psiko drama) dalam layanan BK.

Adapun kontribusi dari penelitian ini diharapkan dapat berdaya transferbilitas luas kepada segenap konselor muslim di dunia, terkhusus bagi konselor yang bernaung di bawah institusi pendidikan Muhammadiyah. Dengan demikian, pemahaman akan rambu-rambu atau batasan dan anjuran syariat dari temuan penelitian ini seyogianya dapat diamalkan pada pelayanan bimbingan konseling Islam, oleh konselor kepada konseli.

\section{Acknowledgments}

Penelitian ini terselenggara dengan baik atas dukungan Dr. Andi Fiptar Abdi Alam, M.Si., selaku Ketua STKIP Muhammadiyah Barru, dan juga kerjasama pimpinan Muhammadiyah Kabupaten Barru atas konfirmasi data serta dukungan morilnya, dengannya dihaturkan banyak terima kasih. Adapun penelitian ini dilaksanakan atas inisiatif pribadi masing-masing dan juga atas persetujuan pimpinan perguruan tinggi peneliti, serta berangkat dengan semangat fastabiqul khaerat untuk Indonesia berkemajuan.

\section{Daftar Pustaka}

Ab Ghani, A. (2019). Batas-batas Pergaulan Antara Lelaki dan Perempuan Dalam Masyarakat Islam Kini: Satu Huraian Hukum Islam Semasa. Jurnal Syariah, 7(1), 23-30.

Afrina, D. (2019). Rasionalitas Muslim terhadap Perilaku Israf dalam Konsumsi Perspektif Ekonomi Islam. EkBis:

\footnotetext{
${ }^{51}$ Wawancara dilaksanakan pada hari Jumat/ 26 Juni 2020, pukul 15.50 Wita.

${ }^{52}$ Wawancara dilaksanakan pada hari Jumat/ 3 Juli 2020, pukul 09.00 Wita.

${ }^{53}$ Moreno, J. L., "Sociodrama In J. L. Moreno", Psychodrama, first Vol (1946).

${ }^{54}$ Moreno, J. L., "Psychodrama and sociodrama", The essential Moreno: Writings on psychodrama, group method, and spontaneity by JL Moreno (1946).

${ }^{55}$ Hayuni, R. R., \& Flurentin, E., "Pengembangan Panduan Sosiodrama untuk Meningkatkan Nilai Peduli Sosial Siswa SMP. Jurnal Kajian Bimbingan dan Konseling 1, no. 3 (2016).

${ }^{56}$ Haryati, A., Wibowo, M. E., \& Mulawarman, M., "Model Bimbingan Kelompok Teknik Sosiodrama untuk Meningkatkan Empati Siswa SMP”, Jurnal Bimbingan Konseling 6, no. 1 (2017).
} 
https://jurnal.lp2msasbabel.ac.id/index.php/sci

Jurnal Ekonomi dan Bisnis, 2(1), 23-38.

Ali, M., Kuntoro, S. A., \& Sutrisno, S. (2016). Pendidikan Berkemajuan: Refleksi Praksis Pendidikan KH Ahmad

Dahlan. Jurnal Pembangunan Pendidikan: Fondasi dan Aplikasi, 4(1), 43-58.

Alvesson, M., \& Sköldberg, K. (2017). Reflexive Methodology: New Vistas for Qualitative Research. Sage.

Anwar, M. F. (2019). Landasan Bimbingan dan Konseling Islam. Deepublish.

Aswar, A., Mappiare-At, A., \& Ramli, M. (2016). Identifikasi Teknik-teknik Pengubahan Tingkah Laku dalam Penerapan Pemikiran Ibnu Qoyyim Al-jauziyyah untuk Pengentasan Korban Seks Bebas dan Homoseks (Kajian Analisis Hermeneutika Bersusun). Jurnal Pendidikan: Teori, Penelitian, dan Pengembangan, 1(2), 196-202.

Aswar, A. I., \& Nur, E. W. (2020). Grooming Konselor Muslim: Panduan Berpenampilan Dalam Kitab Asy-Syama'il Al-Muhammadiyah. Jurnal Bimbingan dan Konseling Islam, 10(01).

Dahlan, F. (2012). Fundamentalisme Agama: Antara Fenomena Dakwah dan Kekerasan Atas Nama Agama. Ilmu Dakwah: Academic Journal for Homiletic Studies, 6(2), 331-346.

Hidayati, O. N., \& Saputro, M. E. (2017). Korean Drama Constructing Multiculturalism Among Muslim Women Students , $A L-A L B A B, 6(1)$.

Haryati, A., Wibowo, M. E., \& Mulawarman, M. (2017). Model Bimbingan Kelompok Teknik Sosiodrama untuk Meningkatkan Empati Siswa SMP. Jurnal Bimbingan Konseling, 6(1), 28-33.

Hamjah, S. H., \& Akhir, N. S. M. (2014). Islamic approach in counseling. Journal of religion and health, 53(1), 279289.

Hayuni, R. R., \& Flurentin, E. (2016). Pengembangan Panduan Sosiodrama untuk Meningkatkan Nilai Peduli Sosial Siswa SMP. Jurnal Kajian Bimbingan dan Konseling, 1(3), 118-125.

Ibrahim, F. A., \& Dykeman, C. (2011). Counseling Muslim Americans: Cultural and spiritual assessments. Journal of Counseling \& Development, 89(4), 387-396.

Indonesia, P. R. (2003). Undang-undang Republik Indonesia nomor 20 tahun 2003 tentang sistem pendidikan nasional. Jakarta: Pemerintah Republik Indonesia.

Ivey, A. E., Ivey, M. B., \& Zalaquett, C. P. (2018). Intentional Interviewing and Counseling: Facilitating Client Development in a Multicultural Society, 9th Edition. Boston: Cenggage Learning. h. 39.

KBBI Daring. https://kbbi.kemdikbud.go.id/entri/pendidikan (Diakses tanggal 12 Agustus 2020).

Mappiare, A. (2013). Tipe-tipe metode riset kualitatif untuk eksplanasi sosial budaya dan bimbingan konseling. Malang: Elang Mas bersama Prodi Bimbingan dan Konseling Fakultas Ilmu Pendidikan Universitas Negeri Malang.

Mappiare-AT, A. (2017). Meramu Model Konseling Berbasis Budaya Nusantara: KIPAS (Konseling Intensif Progresif Adaptif Struktur). Pidato Pengukuhan Jabatan Guru Besar dalam Bidang Ilmu Budaya Konseling pada Fakultas Ilmu Pendidikan. Disampaikan pada Sidang Terbuka Senat Universitas Negeri Malang pada Tanggal, 28.

Muafiah, E. (2013). Pendidikan Perempuan di Pondok Pesantren. Nadwa, 7(1), 89-110.

Muhammadiyah, P. P. (2011). Himpunan Putusan Tarjih Muhammadiyah. Yogyakarta: Suara Muhammadiyah.

Moreno, J. L. (1946). Sociodrama. In J. L. Moreno, Psychodrama, first Vol (p. 350-366).

Moreno, J. L. (1946). Psychodrama and sociodrama. The essential Moreno: Writings on psychodrama, group method, and spontaneity by JL Moreno, 13-19.

Nashir, H. (2010). Muhammadiyah Gerakan Pembaruan. Suara Muhammadiyah. H. 1-2.

Nasional, D. P. (2008). Rambu-Rambu Penyelenggaraan Bimbingan dan Konseling dalam Jalur Pendidikan Formal. Jakarta: Direktorat Jenderal Peningkatan Mutu Pendidikan dan Tenaga Kependidikan Departemen Pendidikan Nasional.

Ramdani, F., \& Aswar, A. (2020). Hablun Minannas Wanita Bercadar (Studi Fenomenologi Interaksi Sosial Wanita Bercadar di Kecamatan Manggala Makassar). NUKHBATUL'ULUM: Jurnal Bidang Kajian Islam, 6(1), 105121.

Situmorang, D. D. B., Mulawarman, M., \& Wibowo, M. E. (2018). Comparison of the Effectiveness of CBT Group Counseling with Passive vs Active Music Therapy to Reduce Millennials Academic Anxiety. International Journal of Psychology and Educational Studies, 5(3), 51-62.

Sutisna, Y., \& Tadjri, I. (2016). Keefektifan Konseling Kelompok Behavioral Teknik Systematic Desensitization Berbantuan Musik Klasik Jawa untuk Mereduksi Communication Apprehension. Jurnal Bimbingan Konseling, 5(1), 74-81.

Tahir, G. (2010). Muhammadiyah (Gerakan Sosial Keagamaan dan Pendidikan). Jurnal Adabiyah, 10(2), 160-169. h. 163.

Tambunan, S. (2018). Seni Islam Terapi Murattal Alquran Sebagai Pendekatan Konseling Untuk Mengatasi Kecemasan. Al-Mishbah: Jurnal Ilmu Dakwah dan Komunikasi, 14(1), 75-89.I 
Scientia: Jurnal Hasil Penelitian Vol. 5, Nomor 2, Desember 2020

EISSN: $2655-3716$

https://jurnal.lp2msasbabel.ac.id/index.php/sci

Yuristiadi, G. (2015). Aktivisme Hoofdbestuur Muhammadiyah Bagian PKO di Yogyakarta Sebagai Representasi Gerakan Pelayanan Sosial Masyarakat Sipil (1920-1931). Afkaruna: Indonesian Interdisciplinary Journal of Islamic Studies, 11(2), 195-219. h. 199. 